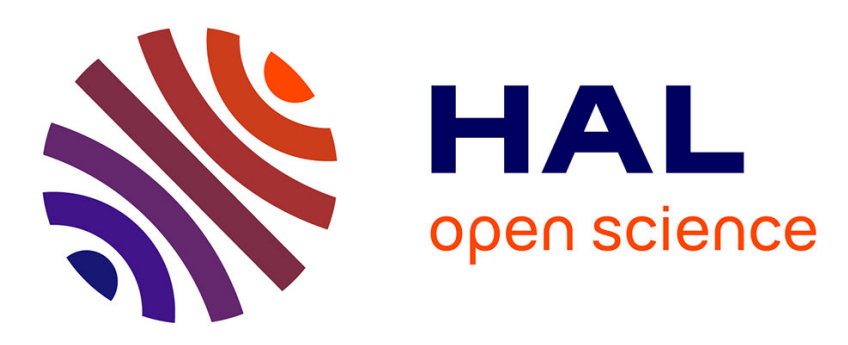

\title{
Medulloblastoma in childhood: revisiting intrathecal therapy in infants and children
}

Sharon Conroy, Martin Garnett, Michael Vloeberghs, Richard Grundy, Ian Craven, David Walker

\section{- To cite this version:}

Sharon Conroy, Martin Garnett, Michael Vloeberghs, Richard Grundy, Ian Craven, et al.. Medulloblastoma in childhood: revisiting intrathecal therapy in infants and children. Cancer Chemotherapy and Pharmacology, 2009, 65 (6), pp.1173-1189. 10.1007/s00280-009-1127-1 . hal-00568268

\section{HAL Id: hal-00568268 \\ https://hal.science/hal-00568268}

Submitted on 23 Feb 2011

HAL is a multi-disciplinary open access archive for the deposit and dissemination of scientific research documents, whether they are published or not. The documents may come from teaching and research institutions in France or abroad, or from public or private research centers.
L'archive ouverte pluridisciplinaire HAL, est destinée au dépôt et à la diffusion de documents scientifiques de niveau recherche, publiés ou non, émanant des établissements d'enseignement et de recherche français ou étrangers, des laboratoires publics ou privés. 


\section{Medulloblastoma in childhood}

\section{- revisiting intrathecal therapy in infants and children}

Sharon Conroy, Lecturer in Paediatric Clinical Pharmacy

Martin Garnett, Associate Professor Pharmaceutical Sciences

Michael Vloeberghs, Professor Paediatric Neurosurgery

Richard Grundy, Professor Paediatric Neuro-Oncology and Cancer Cell Biology

Ian Craven, Research student

David Walker, Professor Paediatric Oncology

Children's Brain Tumour Research Centre,

University of Nottingham,

University Park,

Nottingham

NG7 2RD

UK

Corresponding author: Professor David A Walker

david.walker@nottingham.ac.uk

Tel: +441158230632.

The authors can confirm that this work is original. It was presented as a poster at the $11^{\text {th }}$ International Symposium on Pediatric Neuro-Oncology and the abstract published as below:

Conroy S, Craven I, Garnett M, Barrett S, Punt J, Parker T, Walker DA. An extensive review of chemotherapy agents suitable for intrathecal (IT) therapy in primitive neuro ectodermal tumour (PNET). Abstract EXP 7 from $11^{\text {th }}$ International Symposium on Pediatric NeuroOncology. Neuro-Oncology 2004;6:428

There are no conflicts of interest to declare. This work was conducted without any financial assistance outside of the University of Nottingham

The manuscript has been read and approved by all the authors. Each author believes that the manuscript represents honest work. 


\section{Medulloblastoma in childhood \\ - revisiting intrathecal therapy in infants and children}

\section{Sharon Conroy, Martin Garnett, Michael Vloeberghs, Richard Grundy, Ian Craven and David Walker}

\section{Abstract}

Introduction: Intrathecal chemotherapy is being explored in medulloblastoma in pre-school children as part of brain-sparing strategies and as an alternative to unacceptably neurotoxic cranio-spinal radiotherapy. The range of drugs suitable for this route of administration is restricted by the lack of research evidence of pharmacological suitability and efficacy of other drugs in medulloblastoma.

Methods: Ideal clinical, biological, physicochemical and pharmaceutical properties for intrathecal administration were defined through literature review of pharmaceutical texts, Medline, Embase and consulting the manufacturers. 126 chemotherapy agents were assessed against these criteria by searching the academic domain of pharmaceutical texts, computer databases and consultation with manufacturers.

Results: Of 126 candidates drugs, 99 were rejected because of documentation of their irritant nature, neurotoxicity and requirement for hepatic activation in standard pharmaceutical texts. Fifty were rejected for a single identifiable reason including, neurotoxicity $(n=24)$, irritant $(n=15)$, needs enzyme activation $(n=5)$, clinical evidence of intrathecal neurotoxicity $(n=4)$ and no evidence of tumour-specific efficacy $(n=2)$. Where two reasons were cited the justifications were: neurotoxic and irritant $(n=3)$ and needs activation and systemic administration results in equivalent concentration $(n=1)$. Twenty seven drugs remained of which 12 were selected as eligible for further clinical investigation, and 15 were selected for further pre-clinical investigation.

Conclusions: The predetermined criteria were not applicable, in their entirety, in the majority of drugs, due to lack of information in the academic domain, emphasising the importance of a more open approach to sharing basic drug information. The prioritised list of 12 candidate drugs for clinical trial and 15 for pre-clinical investigation justify that a concerted research effort in this area of practice is made. (317 words) 


\section{Introduction}

Medulloblastoma, the commonest malignant CNS tumour of childhood [125], has the capacity to disseminate through the lepto-meninges, presenting at diagnosis or at relapse after treatment. Leptomeningeal metastases (LM) grow at the interface of the brain and spinal fluid. They are thought to occur as a result of interplay between operative disruption of tumour cells contaminating the CSF and inherent biological capacity for tumour cells to migrate, adhere and invade neural tissue. Where LM are present at diagnosis biological factors are increasingly being associated with this dissemination and poorer cure rates with standard therapy. Systemic chemotherapy has an established role in medulloblastoma with evidence of chemosensitivity, enhanced survival rates and rising survival rates reported by trials groups and population registries [80] in recent eras.

The use of intrathecal chemotherapy in childhood leukaemia and CNS tumours has been the focus of reviews $[17,49,108]$ and reports of phase 1 and 2 studies [17]. In leukaemia the intensification of systemic and intrathecal therapy has permitted exclusion of CNS radiotherapy for the majority of newly diagnosed cases with very low CNS relapse rates, acceptable late toxicity using methotrexate alone or in combination with cytosine and hydrocortisone. The intrathecal route in leukaemia has been demonstrated to bypass the blood brain barrier (BBB), enhance CSF drug concentrations reducing systemic exposure and, therefore, toxicity. Selection of drugs suitable for intrathecal administration and with evidence of sensitivity to primary CNS tumours is a challenge in medulloblastoma, therefore. Preliminary evidence of the efficacy of intrathecal therapy is emerging. Slavc reported extensive use of intrathecal therapy at relapse using etoposide, mafosfamide and others [120,121]. Other studies report the feasibility of this route of drug administration at relapse and as part of palliative care with infrequent complications and prolonged symptom free intervals. Rutkowski reported very high survival rates in pre-school children treated with chemotherapy-only strategy including intraventricular methotrexate [109]. The proposal that intrathecal therapy be tested in a prospective European trial of medulloblastoma in this young age group is currently the focus of debate [139].

In order to further develop an enhanced evidence-base for the selection of drugs that are effective against medulloblastoma, suitable for administration by the intrathecal route, and non-toxic to the nervous system, we developed criteria for the ideal intrathecal agent. Following this a systematic literature review was conducted using these criteria to identify candidate drugs worthy of further trial for intrathecal use in medulloblastoma.

\section{Method}

\section{Identification of candidate drugs}

A comprehensive list of chemotherapy agents was extracted from a drug pharmacopoeia [87]. Properties of the ideal intrathecal drug were identified based upon literature review $[4,10,13$, 
$33,53,102,108,132,136,143,150,151]$ and grouped according to: "ideal clinical properties", "ideal biological properties" and "ideal physico-chemical and pharmaceutical properties".

\section{Ideal Clinical Properties}

Non-irritant

The drug would need to be non-irritant to avoid chemical arachnoiditis or meningitis. Any drug reported in any of our reference sources to cause irritation or thrombophlebitis was therefore eliminated from further consideration.

\section{Neurotoxicity}

Any drug given intrathecally has a significant risk of neurotoxicity. Evidence for neurotoxicity when given systemically or intrathecally was determined as an unacceptable risk for further evaluation of CSF administration. It was not possible to grade the neurotoxicities as they were variably reported. Some drugs which are not usually neurotoxic when given systemically at conventional doses, may be toxic if given intra-arterially, intrathecally or in very high doses [130]. Any drug reported in any of our reference sources to cause neurotoxicity was therefore eliminated from further consideration. Methotrexate and cytosine arabinoside, whilst suitable for IT delivery, have only been studied in medulloblastoma with concurrent systemic chemotherapy agents, the chemosensitivity of medulloblastoma to these drugs is, therefore, unknown.

\section{Tumour sensitivity / mechanism of action}

Evidence of activity of the drug against medulloblastoma, PNET or leptomeningeal carcinomatosis is required to warrant further investigation. A drug with a mechanism of action effective at the CSF/leptomeningeal interface would offer a therapeutic advantage.

\section{Methotrexate and Cytosine Arabinoside}

Interestingly, the strict application of these criteria led to the exclusion of methotrexate and cytarabine (in its standard formulation) from the list of potential candidates. We are aware that these agents are commonly used intrathecally. The application of 'ideal criteria' which identifies lack of chemosensitivity data and substantial evidence of neurotoxicity led to their rejection from our ideal list, for the purposes of this review.

\section{Ideal Biological properties}

CSF transport system

Some drugs are removed from the CSF by facilitated diffusion using carrier transport systems such as those for organic ions, quaternary ammonium compounds, organic bases and acids, also transporters conferring multi-drug resistance such as P-glycoprotein, multi-drug resistance protein 1 , monocarboxylic acid and organic ion transporters [126]. The ideal 
intrathecal agent will have no active transport system that is capable of removing it from the CSF.

Cell cycle non-specific agent

Cells in the process of dissemination may be in a non-cycling, $\mathrm{G}_{0}$, or slow cycling phase. Drugs which act at specific stages of the cell cycle will need to be in contact with the cells for sufficient time for the cells to go through active cell division, to ensure an effective cell kill. An ideal agent would therefore be cell cycle non-specific in its action.

\section{Ideal Physicochemical and pharmaceutical properties}

Active in CSF

Drugs requiring enzyme activation (e.g. cyclophosphamide) are unlikely to be active since there are very few enzyme systems present in the CSF. Drugs administered in their active form or with predictable activation (e.g. hydrolysis) are proposed. Those requiring other processes of activation are excluded.

\section{Factors affecting BBB permeability}

Drugs in the CSF are likely to be in equilibrium with plasma as determined by the characteristics of the BBB and the drug's physical characteristics. Factors that reduce a drug's capacity to diffuse across the BBB and therefore limit drug efflux include: low lipophilicity, high hydrophilicity, ionised state at CSF pH of 7.3 and molecular weight $>700 \mathrm{Da}$ [53]. Such properties should therefore enhance sustained CSF drug levels and are therefore preferred for intrathecal therapy.

\section{Protein binding}

Ideally drugs normally protein bound are excluded from crossing the BBB due to molecular size, direct injection would overcome this and sustain their presence in CSF. This criteria has, however, not been used as the information was not available for the majority of drugs.

\section{Formulation for CSF administration}

The drug must be soluble in the appropriate concentration for intrathecal administration, and in a vehicle which is suitable for this route, including bio-compatibility with surgical delivery systems such as ventriculostomy reservoirs.

(Insert Table 1 here - Summary of clinical, biological and physicochemical / pharmaceutical properties used to justify selection or rejection of drugs)

\section{Literature search strategy and selection criteria}

An initial search for the properties of each drug on the candidate list was undertaken by screening standard pharmaceutical texts $[9,30,87]$ and by consulting the manufacturer. 
Some information was obtained from these sources. This permitted immediate elimination of a number of drugs due to evidence of irritancy, neurotoxicity and the need for liver enzyme activation. However details of ionisation state and degree of protein binding for many drugs was unavailable despite direct approaches to manufacturers.

For the remaining drugs, Medline (1966 - present) and Embase (1980 - present) searches were performed. Each drug name was separately combined with the following terms: 'medulloblastoma', 'PNET' and 'leptomeningeal carcinomatosis', used in the 'exploded' form. Where hits exceeded 50 for a combination of terms, the search was further narrowed by combining that search with 'intrathecal administration'. The full text of papers with relevant abstracts were obtained and physicochemical information was extracted as well as:

- evidence of the drug's activity against medulloblastoma, PNET and leptomeningeal carcinomatosis in vitro and in vivo

- absence or presence of neurotoxicity reported from systemic or intrathecal administration

- documentation of intrathecal administration in vivo and in vitro.

\section{Results}

One hundred and twenty-six drugs were initially identified for investigation. 35 were immediately rejected after consulting standard pharmaceutical texts where there was documentation of irritant qualities, neurotoxicity or the need for enzyme activation of a prodrug. Literature searches for the remaining 91 drugs identified 33,627 hits. Screening of abstracts reduced this to 200 full papers which were read, justifying the rejection of a further 64 drugs (see Table $2 a \& b$ ).

(Insert Table 2 here - List of chemotherapy drugs considered with selection / rejection status and rejection justification)

\section{Rejected drugs}

Of the 126 licensed and investigational anti-cancer chemotherapy agents identified, 99 drugs were excluded (Table $2 a \& b$ ). In 45 cases rejection was due solely to the lack of information. The remaining 54 drugs were rejected for a single reason $(n=50)$ or a combination of two reasons $(n=4)$. Where a single reason is cited the justifications were: neurotoxicity $(n=24)$, irritant $(n=15)$, needs activation $(n=5)$, neurotoxic when given intrathecally $(n=4)$, lack of activity in relevant tumour type $(n=2)$. Where two reasons were cited, the justifications were: neurotoxic and irritant $(n=3)$, and needs activation and systemic administration results in equivalent concentration $(n=1)$. 
From our initial list of 126 drugs, 12 drugs have been identified as suitable for further testing by the intrathecal route in medulloblastoma. Fifteen other potential candidates lack sufficient information to currently justify exploration of intrathecal administration, but warrant further research. The 27 drugs are therefore candidates for further testing via the intrathecal route focussed upon in childhood medulloblastoma and other leptomeningeal malignancies.

The most promising 12 drugs for PNET/medulloblastoma with prior reported clinical experience are detailed in Table 3 with justification of their potential for future research.

(Insert Table 3 here - Drugs currently eligible for consideration for trial by intrathecal administration for medulloblastoma)

\section{Evaluation in progress}

Liposomal cytarabine and mafosfamide are currently undergoing phase 2 trials by the intrathecal route in children with brain tumours with leptomeningeal spread. Liposomal cytarabine has now been associated with significant neurotoxicity, particularly in adult patients also treated with systemic cytarabine [16]. It may be better tolerated in children. Comitant systemic corticosteroid treatment is recommended. Further studies are needed to establish optimal use of this drug.

These should be the first drugs to undergo further evaluation in phase 3 studies in order to further evaluate their efficacy and toxicity profiles and optimise dose and administration regimens.

\section{Evaluation required in Phase 2 trials}

Carboplatin, etoposide, spartaject, busulfan and nimustine are agents suitable for treatment of PNET and are therefore also suitable for further investigation by the intrathecal route. Topotecan is undergoing intrathecal phase 2 studies in children and adults with refractory neoplastic meningitis; however chemical arachnoiditis has been reported as a dose limiting toxicity. Etoposide and nimustine have already been tested clinically with some encouraging results; however refinement of drug delivery systems may be necessary to prolong exposure in order to overcome their rapid removal from the CSF, their currently observed efficacy may, therefore, be sub-optimal.

\section{Phase 1 studies required}

Floxuridine and 4-hydroperoxycyclophosphamide have been tested intrathecally in limited studies and have shown promise in relevant tumour types. The intrathecal use of these two agents should also be further explored. 
Diaziquone is lipophilic and has low ionisation at CSF pH. Together these physical properties suggest it may not remain in the CSF unless delivered in a sustained release formulation or as an infusion. It is active in PNET and leptomeningeal carcinomatosis and has been used intrathecally in human studies. Mercaptopurine has been tested by the intraventricular route in animals and children with leptomeningeal dissemination of ALL but there is no evidence of efficacy in primary brain tumours. Rubitecan has been shown to be safe $\&$ effective in a rat model against human glioblastoma multiforme neoplastic meningitis.

Temozolomide is effective in medulloblastoma when given orally. A microcrystalline preparation has been used intrathecally in animal studies justifying further study if an appropriate formulation could be developed. Its lipophilicity would favour a sustained release formulation or an infusion

\section{Pre-clinical animal evaluation}

The nine drugs in Table 4 have documented activity in the relevant tumour types but no information was found on intrathecal use. These drugs would be worthy of intrathecal testing.

(Insert Table 4 here - Drugs with documented activity in the relevant tumour types but no information on intrathecal use)

The drugs in Table 5 have been tested in studies in the relevant tumour types by the intrathecal route (some animal, some human) with mixed reports of toxicity and efficacy. With the exception of bleomycin where neurotoxicity seems to be a major problem, these may well be worthy of further research. Carmustine is licensed in a sustained release preparation designed to be implanted into tumour resection cavities as an adjunct to surgery for GBM after relapse. However, it is documented also to have serious neurotoxicity when given systemically and therefore has not been prioritised in the list of drugs for further study.

Gemcitabine has been tested by the intrathecal route in a patient with leptomeningeal carcinomatosis from non small cell lung cancer and has been used intrathecally in non-human primate models $[35,45,67]$. Based upon this, a phase 1 clinical trial of intrathecal gemcitabine has been conducted in ten patients with neoplastic meningitis including one with medulloblastoma. However, dose limiting neurotoxicity was observed in patients who had previously received CNS-directed therapies [15] The authors concluded that the potential for severe neurotoxicity precludes further development of gemcitabine for intrathecal administration.

(Insert Table 5 here - Drugs tested by the intrathecal route (some animal, some human) with mixed reports of toxicity and efficacy) 


\section{Discussion}

This work helps draw three important conclusions. First, many of the proposed ideal criteria, have not been applicable because of inadequate data in the academic and commercial information domains. A more open shared strategy between pharma and academic researchers of basic pharmacological data is required. Secondly, using supplementary clinical criteria, the systematic review has identified 12 drugs suitable for immediate intrathecal use in medulloblastoma, 15 other candidate drugs were identified for further evaluation prior to human use. Finally, the extended list of agents, identified here as suitable for intrathecal use, justifies further efforts to explore their role as part of brain sparing strategies in clinical trials.

\section{Ideal criteria}

The pre-determined criteria were applicable in their entirety in only eight drugs resulting in the current drug selection being based primarily upon alternative criteria including: a) clinical evidence of tumour chemo-sensitivity, b) previously reported intrathecal use and c) reported evidence of neurotoxicity after systemic or intrathecal administration. The overwhelming reason for rejection was because of either insufficient or inconsistent information in the academic domain (Table 2). It remains unclear why this basic physicochemical data is unavailable, highlighting the importance of promoting a more open ethic between pharma and academic groupings exploring novel applications of existing cancer drugs and in particular for intrathecal administration. This large category of known, rejected drugs as well as a presumed larger number of unknown candidate agents in industrial archives constitutes an untapped resource. In contrast, drugs with inconsistent data, but promising early laboratory or clinical evidence of suitability, are a group where further efforts for their evaluation are justified. Furthermore, as new biological agents are developed which affect tumour behaviour via non cytotoxic mechanisms, the lack of publication of physico-chemical criteria or clinical pharmacological data will slow down the process of their selection or rejection for intrathecal use.

Drug selection: From this review, 12 agents were identified as potentially suitable for human use. The three largest previous reviews of this treatment approach do specify optimal drug criteria for intrathecal use but do not specify the method by which they developed their proposed drug selections for intrathecal use.

(Insert Table 6 here - Comparison of candidate intrathecal agents by previous published reviews)

The current review has identified four additional drugs: carboplatin, floxuridine, 4hydroperoxycyclophosphamide and rubitecan, yet rejected cytarabine (in its standard formulation) and methotrexate because of evidence of neurotoxicity. The extensive experience with these two latter drugs for prophylactic, therapeutic and palliative strategies in acute 
leukaemia and lymphoma has permitted comprehensive reporting of neurotoxicity. It has been proposed that enhanced and prolonged drug levels due to reduced permeability of the BBB arising from tumour involvement at sites of CSF efflux is a hypothesis for this observed effect $[23,24,55,86]$. Carmustine in its wafer preparation ( ${ }^{\mathrm{TM}} \mathrm{Gliadel}$ ) is used for interstitial therapy for GBM at relapse (ref). Prior reports of neurotoxicity after intra-arterial administration might have excluded this drug. Its lipophilicity makes it unsuitable as an intrathecal agent without adaptation to its formulation to slow its release or as an infusion. Its current application within a sustained release wafer is, therefore, compatible with the 'ideal criteria' based upon physicochemical properties but not via the intrathecal route aimed at generalised CSF distribution.

Nine drugs were identified with evidence of efficacy against medulloblastoma but insufficient information about their suitability for intrathecal use (Table 4). More information about their physicochemical / cycle specific and neurotoxicity properties is required before they could be accepted/rejected for evaluation by the ideal criteria. The information that was missing was physicochemical (7), cell cycle specificity (4) and neurotoxicity (7). The previous reviews [17, $49,108]$ made no suggestions for this category of agents. Drugs, tested by the intrathecal route but with mixed reports of toxicity ( $n=7$ Table 5$)$, were based upon clinical case reports from both animal and human experimentation, limiting the scope of this group as a source of new drugs for testing. There were conflicting reports of neurotoxicity. In only one drug was there a complete physico-chemical dataset (dacarbazine). In three drugs (bleomycin, busulfan and carmustine) drug formulation was reported to influence neurotoxicity and efficacy. This group of drugs highlights the importance of selecting or developing drug formulations that maximise efficacy and minimise neurotoxicity.

Having identified a short list of 12 drugs suitable for human trial via the intrathecal route (table 3) an attempt to select those suitable for immediate use has been made based upon currently available data. Carboplatin, etoposide and nimustine are identified as having the strongest evidence base for intrathecal use. Liposomal cytarabine (Depocyte) and mafosfamide are currently undergoing phase 2 trials; their efficacy and toxicity will need to be judged when given without concomitant chemotherapy or radiotherapy. Mafosfamide is unlicensed and is therefore unavailable for clinical use in trial or therapy (Personal communication: Irene Slavc - irene.slavc@akh-wien.ac.at; Dr Susan Blaney: smblaney@txccc.org). Liposomal cytarabine (Depocyte) is being extensively investigated in adult studies in a variety of cancer types. Preliminary information has identified substantial evidence of neurotoxicity $[65,81]$. In selecting any of these drugs for use, the more fat soluble drugs will require either a pharmaceutical formulation aimed at prolonging drug release or the use of intrathecal infusions to sustain drug levels. Such infusional techniques are well developed for intrathecal baclofen aimed at controlling spasticity and could be adapted for such an application [123]. 
Limitations: Our criteria for accepting or rejecting drugs were applied strictly therefore. Any drug for which we found documentation of it being irritant or neurotoxic was rejected. It is possible that this criteria was applied too strictly since, for example, methotrexate and cytarabine (standard formulation) were excluded and liposomal cytarabine (Depocyte) has been accepted but evidence of neurotoxicity is now emerging. However the objective of the study was to identify drugs with ideal characteristics for intrathecal use.

It is difficult to interpret many studies of intrathecal chemotherapy in terms of efficacy, as in many cases simultaneous systemic chemotherapy or radiation, or both were administered along with intrathecal treatment making it unclear which component of therapy produced the effect. Most patients recruited into such studies are refractory to other treatments and are therefore undergoing such trials as a 'last resort'. Despite this, measurable response to IT therapy, introduced after systemic chemotherapy has proved refractory, is reported as evidence of effect.

Drug administration: The clinical benefits of intrathecal administration need to be balanced against the risks relating to safe prescribing, clinical governance, technical and toxicity issues [38]. Furthermore, in contrast to leukaemia and lymphomas, primary CNS tumours represent anatomical challenges to drug distribution linked to the presence of ventrico peritoneal (VP) shunts, the influence of drainage of the third ventricle to basal cistern by neuroendoscopic third ventriculostomy, distortion of CNS anatomy linked to post-resection tumour bed, post operative incarceration of the posterior fossa and spinal blocks. Finally, the ideal timing of intrathecal administration in relation to debulking surgery is unclear. Such factors will clearly influence the distribution of CSF and any drug it carries. The challenges of drug delivery to the brain have resulted in a considerable volume of research, which may overcome some of these problems, through either local delivery approaches $[105,140]$ or vascular delivery across the blood brain barrier $[57,79,103]$. However, relatively little research has been focussed upon delivery systems for intrathecal delivery, the main example being that of liposomal cytarabine [22]. The role of efflux inhibitors such as valspodar in combination with intrathecal therapy in order to overcome the problems of removal of drugs from the CSF by multi-drug resistance transporters could also be explored [126].

The application of this method of drug administration in medulloblastoma is timely, as cure rates with combined chemo-radiotherapy for both localised and metastatic cases are improved (>70\%, 5 year survival) in school age children. Novel biological markers are identifying patients with favourable tumour types where further de-escalation of neuro-toxic cranial radiotherapy by adjustments to dose/fractionation schedules or fields. The role of systemic 
chemotherapy, whilst established in this age group, will be further examined in trials focussing upon minimising toxicity.

In pre-school age children with favourable presentations (non-metastatic, completely resected, desmoplastic histology) survival rates also exceed 70\% in recently reported studies [54, 109] using both low and high intensity chemotherapy schedules with or without intrathecal methotrexate and with or without involved field radiotherapy. The interaction between biological markers and these treatment strategies in this age group is yet to be studied [8,58, 110]. The role of chemotherapy is, therefore, established. The potential for novel biological agents is yet to be explored but is anticipated.

\section{Selecting drugs for IT trial}

The most effective and safe way of delivering a drug to the leptomeningeal CSF interface will continue to be a challenge. In seeking to optimise drug delivery, drug selection is the first step. The route and method of administration will need to be studied further i.e. the intraventricular route, the lumbar route, by bolus and by infusion. Anatomical factors will require consideration including the effects of tumour location, CSF circulation, including VP shunting and post operative complications affecting the tumour bed. Once drugs have been tested in phase 1 studies, then phase 2 studies looking for efficacy in patients with either newly presenting or relapsed leptomeningeal disease will be necessary. Once a drug has been assessed as effective by intermittent or infusional techniques of IT administration, then phase 3 trials to evaluate its clinical effectiveness or preparation of sustained release formulation for intermittent IT administration would be justified. The preparatory clinical testing can only be developed within centres with the relevant neuroscience / pharmaceutical / pharmacological research expertise.

\section{Conclusion}

This review has extended the list of candidate agents suitable for further investigation of intrathecal treatment of leptomeningeal medulloblastoma. It has identified the importance of making basic physico-chemical criteria available to the academic domain by pharma and academic research groupings in order to accelerate the development of new cancer agents. It has highlighted the opportunity to replicate the success of CNS targeting of drug therapy in leukaemia and lymphoma, by proposing trials of novel intrathecal chemotherapy in medulloblastoma. It has identified the need to establish an acceptable process for selecting new drugs for trial and a suitable trial design.

\section{Acknowledgements:}

This work has been supported by funding from the Children's Brain Tumour Research Centre at the University of Nottingham. 
We would like to acknowledge the assistance of Professor Imti Choonara in the development of strategy and review of the manuscript, Steve Barrett in the conduct of the literature searching and Sue Franklin in the preparation of the manuscript.

(Word count 3919) 


\section{References:}

[1] Interactive analysis $\log \mathrm{P}$ and LogW Predictors. www.logp.com.

[2] (1998) Gliadel wafers for treatment of brain tumors. The Medical Letter 40: 92

[3] Aaron R, Elion G, Colvin O, Graham M, Keir S, Bigner D, Friedman H (1994) Busulfan therapy of central

nervous system xenografts in athymic mice. Cancer Chemotherapy \& Pharmacology 35: 127-131

[4] Allinson R, Stach P (1978) Intrathecal drug therapy. Drug Intelligence and Clinical Pharmacy 12: 347-359

[5] Archer G, Sampson J, McLendon R, Friedman A, Colvin O, Rose M, Sands H, McCullough W, Fuchs H,

Bigner D, Friedman H (1999) Intrathecal busulfan treatment of human neoplastic meningitis in athymic nude rats.

Journal of Neuro-Oncology 44: 233-241

[6] Arita N, Ushio Y, Hayakawa T, Nagatani M, Huang T-Y, Izumoto S, Mogami H (1988) Intrathecal ACNU - a new therapeutic approach against malignant leptomeningeal tumors. Journal of Neuro-Oncology 6: 221-226

[7] Arndt C, Colvin O, Balis F, Lester C, Johnson G, Poplack D (1987) Intrathecal administration of 4-

hydroperoxycyclophosphamide in rhesus monkeys. Cancer Research 47: 5932-5934

[8] Ashley D, Merchant T, Zhou T, Coleman L, Pollack I, Duffner P, Burger P, Miller D, Buxton A, Douglas S (2008) Systemic chemotherapy, second-look surgery and conformal radiation therapy limited to the posterior fossa and primary site for children $>8$ months and $<3$ years with non-metastatic medulloblastoma: A Children's Oncology Group phase III study. Neuro-Oncology 10: 436-437

[9] Association of the British Pharmaceutical Industry (1999) ABPI Compendium of data sheets and summaries of product characteristics 1999-2000. Datapharm Publications, London.

[10] Baker S, Heideman RL, Crom WR, Kuttesch J, Gajjar A, Stewart C (1996) Cerebrospinal fluid pharmacokinetics and penetration of continuous infusion Topotecan in Children with central nervous system tumours. Cancer Chemotherapy \& Pharmacology 37: 195-202

[11] Bates S, Raphaelson M, Price R, McKeever P, Cohen S, Poplack D (1985) Ascending myelopathy after chemotherapy for central nervous system acute lymphoblastic leukemia: correlation with cerebrospinal fluid myelin basic protein. Medcial \& Pediatric Oncology 13: 4-8

[12] Bayer (1999) Information from Medical Information Department. Newbury, Berkshire.

[13] Bender J, Grillo-Lopez A, Posada Jnr J (1983) Diaziquone (AZQ). Investigational New Drugs 1: 71-84

[14] Berg S, Balis F, Zimm S, Murphy R, Holcenberg J, Sato J, Reaman G, Steinherz P, Gillespie A, Doherty K, Poplack D (1992) Phase I/II trial and pharmacokinetics of intrathecal diaziquone in refractory meningeal malignancies. Journal of Clinical Oncology 10: 143-148

[15] Bernardi R, Bomgaars L, Fox E, Balism F, Egorin M, Lagattuta T, Aikin A, Whitcome P, Renbarger J, Lieberman F, Berg S, Blaney S (2008) Phase I clinical trial of intrathecal gemcitabine in patients with neoplastic meningitis. Cancer Chemotherapy \& Pharmacology 62: 355-361

[16] Bhojwani D, Pui C-H (2008) Intrathecal liposomal cytarabine: more friend than foe? Leukaemia \& Lymphoma 49: $1427-1430$

[17] Blaney S, Boyett J, Friedman H, Gajjar A, Geyer R, Horowitz M, Hunt D, Kieran M, Kun L, Packer R, Phillips P, Pollack M, Prados M, Heideman R (2005) Phase I clinical trial of mafosfamide in infants and children aged 3 years or younger with newly diagnosed embryonal tumors: A Pediatric Brain Tumor Consortium study (PBTC-001). Journal of Clinical Oncology 23: 525-531

[18] Blaney S, Cole D, Godwin K, Sung C, Poplack D, Balis F (1995) Intrathecal administration of topotecan in nonhuman primates. Cancer Chemotherapy \& Pharmacology 36: 121-124

[19] Blaney S, Heideman R, Berg S, Adamson P, Gillespie A, Geyer J, Packer R, Matthay K, Jaeckle K, Cole D, Kuttesch N, Poplack D, Ballis F (2003) Phase I clinical trial of intrathecal topotecan in patients with neoplastic meningitis. Journal of Clinical Oncology 21: 143-147

[20] Blaney S, Poplack D (1996) Pharmacologic strategies for the treatment of meningeal malignancy. Investigational New Drugs 14: 69-85

[21] Blaney S, Poplack D (1998) New cytotoxic drugs for intrathecal administration. Journal of Neuro-Oncology 38: $219-223$

[22] Bleyer W (1999) Intrathecal depot cytarabine therapy: a welcome addition to a limited armametarium. Clinical Cancer Research 5: 3349-3351

[23] Bleyer W, Coccia P, Sather H, et al (1983) Reduction in central nervous system leukemia with a pharmacokinetically derived intrathecal methotrexate dosage regimen. Journal of Clinical Oncology 1: 317-325

[24] Bleyer W, Drake J, Chabner B (1973) Neurotoxicity and elevated cerebrospinal fluid methotrexate concentration in meningeal leukemia. New England Journal of Medicine 289: 770-773

[25] Boiardi A, Eoli M, Pozzi A, Salmaggi A, Broggi G, Silvani A (1999) Locally delivered chemotherapy and repeated surgery can improve survival in glioblastoma patients. Ital J Neurol Sci 20: 43-48

[26] Boland I, Vassal G, Morizet J, Terrier-Lacombe M-J, Valteau-Couanet D, Kalifa C, Hartmann O, Gouyette A

(1999) Busulphan is active against neuroblastoma and medulloblastoma xenografts in athymic mice at clinically achievable plasma drug concentrations. British Journal of Cancer 79: 787-792

[27] Bomgaars L, Geyer J, Franklin J, Dahl G, Park J, Winick N, Klenke R, Berg S, Blaney S (2004) Phase I trial of intrathecal liposomal cytarabine in children with neoplastic meningitis. Journal of Clinical Oncology 19: 3916-3921 
[28] Brandes A, Pasetto L, Monfardini S (2000) New drugs in recurrent high grade gliomas. Anti-Cancer Research 20: $1913-1920$

[29] Brem H, Piantadosi S, Burger P, Walker M, Selker R, Vick N, Black K, Sisti M, Brem S, Mohr G, Muller P, Morawetz R, Schold S (1995) Placebo-controlled trial of safety and efficacy of intraoperative controlled delivery by biodegradable polymers of chemotherapy for recurrent gliomas. Lancet 345: 1008-1012

[30] British Medical Association \& Royal Pharmaceutical Society of Great Britain (2000) British National Formulary. BMA \& RPS (GB), London.

[31] Castleberry R, Ragab A, Steuber C, Kamen B, Toledano S, Starling K, Norris D, Burger P, Krischer J (1990) Aziridinylbenzoquinone (AZQ) in the treatment of recurrent pediatric brain and other malignant solid tumors. Investigational New Drugs 8: 401-406

[32] Chamberlain M, Khatibi S, Kim J, Howell S, Chatelut E, Kim S (1993) Treatment of Leptomeningeal Metastasis with Intraventricular Administration of Depot Cytarabine (DTC101). Archives of Neurology 50: 261-264

[33] Chamberlain M, Kormanik P, Howell S, Kim S (1995) Pharmacokinetics of Intralumbar DTC-101 for the Treatment of Leptomeningeal Metastases. Archives of Neurology 52: 912-917

[34] Champagne M, Silver H (1992) Intrathecal Dacarbazine Treatment of Leptomeningeal Malignant Melanoma. Journal Of The National Cancer Institute 84: 1203-1204

[35] Chen Y-M, Chen M-C, Tsai C-M, Perng R-P (2003) Intrathecal gemcitabine chemotherapy for non-small cell lung cancer patients with meningeal carcinomatosis - a case report. Lung Cancer 40: 99-101

[36] Crawford S, Rustin G, Bagshawe K (1986) Acute neurological toxicity of intrathecal cytosine arabinoside. Cancer Chemotherapy \& Pharmacology 16: 306-307

[37] Damon L, Plunkett W, Linker C (1991) Plasma and Cerebrospinal Fluid Pharmacokinetics of 1- $\beta$ - DArabinofuranosylcytosine and 1- $\beta$ - D-Arabinofuranosyluracil following the Repeated Intravenous Administration of High- and Intermediate-Dose $\beta$ - D-Arabinofuranosylcytosine. Cancer Research 51: 4141-4145

[38] Department of Health (2008) Updated national guidance on the safe administration of intrathecal chemotherapy. In: Health Do (ed).

[39] Dodion P, Sanders C, Georges P, Kenis Y (1988) In vitro chemosensitivity of brain tumors to cisplatin and its analogues, iproplatin and carboplatin. Cancer Chemotherapy \& Pharmacology 22: 80-82

[40] Dollery C (ed) (1999) Therapeutic drugs. Churchill Livinstone, Edinburgh.

[41] Doz F, Pinkerton R (1994) What is the Place of Carboplatin in Paediatric Oncology? European Journal of Cancer 30A: 194-201

[42] Drayton C (ed) (1990) Comprehensive medicinal chemistry. Pergamon Press, Oxford.

[43] Eagan R, Dinapoli R, Cascino T, Scheithauer B, O'Neill B, O'Fallon R (1987) Comprehensive phase II evaluation of Aziridinylbenzoquinone (AZQ, Diaziquone) in recurrent human primary brain tumors. Journal of NeuroOncology 5: 309-314

[44] Edwards M, Levin V, Seager M, Wilson C (1981) Intrathecal Chemotherapy for Leptomeningeal Dissemination of Medulloblastoma. Child`s brain 8: 444-451

[45] Egorin M, Zuhowski E, McCully C, Blaney S, Kerr J, Berg S, Ballis F (2002) Pharmacokinetics of intrathecal gemcitabine in non-human primates. Clinical Cancer Research 8: 2437-2442

[46] Englehard H (2000) The role of interstitial BCNU chemotherapy in the treatment of malignant glioma. Surg Neurol 53: 458-464

[47] Ettinger L, Ru N, Krailo M, Ruccione K, Krivit W, Hammond G (1990) A phase II study of diaziquone in children with recurrent or progressive primary brain tumors: A report from the Children's Cancer Study Group. Journal of Neuro-Oncology 9: 69-76

[48] Ewend M, Sampath P, Williams J, Tyler B, Brem H (1998) Local delivery of chemotherapy prolongs survival in experimental brain metastases from breast carcinoma. Neurosurgery 43: 1185-1193

[49] Fleischhack G, Jaehde U, Bode U (2005) Pharmacokinetics following intraventricular administration of chemotherapy in patients with neoplastic meningitis. Clin Pharmacokinet 4: 1-31

[50] Friedman H (2000) Temozolomide in early stages of newly diagnosed malignant glioma and neoplastic meningitis. Seminars in Oncology 27: 35-40

[51] Friedman H, Bigner S, Bigner D (1995) Cyclophosphamide therapy of medulloblastoma: from the laboratory to the clinic and back again (and again and again). Journal of Neuro-Oncology 24: 103-108

[52] Friedman H, Ochs J, Finlay J, Geyer R, Arndt C, Cohen B, Phillips P, Strauss L, Hochberg F, Schold S, Bigner D, Colvin O (1993) Phase I trial of intrathecal 4-hydroperoxycyclophosphamide for neoplastic meningitis. American Association for Cancer Research. p. 269.

[53] Green L (1988) Choice of diluents for intrathecal drug administration. Clinical Pharmacy 7: 265-266

[54] Grill J, Sainte-Rose C, Jouvet A, Gentet J-C, Lejars O, Frappaz D, Doz F, Rialland X, Pichon F, Bertozzi A-I, Chastagner P, Couanet D, Habrand J-L, Raquin M-A, Le Deley M-C, Kalifa C (2005) Treatment of medulloblastoma with postoperative chemotherapy alone: an SFOP prospective trial in young children. Lancet Oncology 6: 573-580 [55] Grossman S, Trump DL, Chen D, Thompson G, Camargo E (1982) Cerebrospinal fluid flow abnormalities in patients with neoplastic meningitis. An evaluation using ${ }^{111}$ Indium DTPA ventriculography. American Journal of Medicine 73: 641-647 
[56] Gururangan S, Petros W, Young Poussaint T, Hancock M, Phillips P, Friedman H, Bomgaars L, Blaney S, Kun L, Boyett J (2006) Phase I trial of intrathecal Spartaject Busulfan in children with neoplastic meningitis: a Pediatric Brain Tumor Consortium study (PBTC-004). Clinical Cancer Research 12: 1540-1546

[57] Gutman R, Peacock G, Lu D (2000) Targeted drug delivery for brain cancer treatment. J Controlled Release 65: $31-41$

[58] Haberler C, Varlet P, Legoix P, Fattet S, Janoueix-Lerosey I, Lellouch-Tubiana A, Grill J, Doz F, Sainte-Rose C, Delattre O (2008) Widespread nuclear beta-catenin expression in medulloblastoma correlates with mutation status of CTNNB1 gene encoding beta-catenin. Neuro-Oncology 10: 470

[59] Hare C, Elion G, Houghton P, Houghton J, Keir S, Marcelli S, Bigner D, Friedman H (1997) Therapeutic efficacy of the topoisomerase I inhibitor 7-ethyl-10-(4-[1-piperidino]-1-piperidino)-carbonyloxy-camptothecin against pediatric and adult central nervous system tumor xenografts. Cancer Chemotherapy \& Pharmacology 39: 187-191 [60] Heideman RL, McCully C, Balis F, Poplack D (1993) Cerebrospinal fluid pharmacokinetics and toxicology of intraventricular and intrathecal arabinosyl-5-azacytosine (fazarabine, NSC 281272) in the nonhuman primate. Investigational New Drugs 11: 135-140

[61] Hori T, Tanaka S, Nishiyama M, Kamitani H, Watanabe T, Tabuchi F, Tatsuhara T, Nakajima E (1993) Distribution of intrathecally administered ACNU in mongrel dogs: Pharmacokinetics and quantitative autoradiographic study. Surg Neurol 40: 183-195

[62] Houchens D, Ovejera A, Riblet S, Slagel D (1983) Human brain tumor xenografts in nude mice as a chemotherapy model. European Journal of Cancer \& Clinical Oncology 19: 799-805

[63] Huang T-Y, Howng S-L (1997) Intrathecal ACNU against experimental leptomeningeal tumors. Kaohsiung J Med Sci 13: 626-630

[64] Hussain M, Wozniak A, Edelstein M (1993) Neurotoxicity of antineoplastic agents. Critical Reviews in Oncology/Hematology 14: 61-75

[65] Jabbour E, O'Brien S, Kantarjian H, Garcia-Manero G, Ferrajoli A, Ravandi F, Cabanillas M, Thomas DA (2007) Neurologic complications associated with intrathecal liposomal cytarabine given prophylactically in combination with high-dose methotrexate and cytarabine to patients with acute lymphocytic leukemia. Blood 109: 3214-3218

[66] Jaeckle K, Batchelor T, O'Day S, Phuphanich S, New P, Lesser G, Cohn A, Gilbert M, Aiken R, Heros D, Rogers L, Wong E, Fulton D, Gutheil J, Baidas S, Kennedy J, Mason W, Moots P, Russell C, Swinnen L, Howell S (2002) An open label trial of sustained-release cytarabine (DepoCyt) for the intrathecal treatment of solid tumor neoplastic meningitis. Journal of Neuro-Oncology 57: 231-239

[67] Kerr J, Berg S, Dauser R, Nuchtern J, Egorin M, McGuffey L, Aleksic A, Blaney S (2001) Plasma and cerebrospinal fluid pharmacokinetics. Cancer Chemotherapy \& Pharmacology 47: 411-414

[68] Kim S, Chatelut E, Kim J, Howell S, Cates C, Kormanik P, Chamberlain M (1993) Extended CSF Cytarabine Exposure Following Intrathecal Administration of DTC 101. Journal of Clinical Oncology 11: 2186-2193

[69] Kim S, Khatibi S, Howell S, McCully C, Balis F, Poplack D (1993) Prolongation of Drug Exposure in Cerebrospinal Fluid by Encapsulation into DepoFoam. Cancer Research 53: 1596-1598

[70] Kim S, Kim D, Geyer M, Howell S (1987) Multivesicular Liposomes Containing 1- $\beta$ - DArabinofuranosylcytosine for Slow-Release Intrathecal Therapy. Cancer Research 47: 3935-3937

[71] Kimler B, Liu C, Evans R, Morantz R (1992) Intracerebral chemotherapy in the 9L rat brain tumor model. Journal of Neuro-Oncology 14: 191-200

[72] Kitamura I, Kochi M, Matsumoto Y, Ueoka R, Kuratsu J-I, Ushio Y (1996) Intrathecal chemotherapy iwth 1,3Bis(2-chloroethyl)-1-nitrosourea encapsulated into hybrid liposomes for meningeal gliomatosis: An experimental study. Cancer Research 56: 3986-3992

[73] Kleinschmidt-DeMasters B, Yeh M (1992) "Locked-in syndrome" after intrathecal cytosine arabinoside therapy for malignant immunoblastic lymphoma. Cancer 70: 2504-2507

[74] Kochi M, Kuratsu J-I, Mihara Y, Takaki S, Inoue N, Sueyoshi N, Uemura S, Ushio Y (1990) Neurotoxicity and pharmacokinetics of intrathecal perfusion of ACNU in dogs. Cancer Research 50: 3119-3123

[75] Kochi M, Kuratsu J-I, Mihara Y, Takaki S, Seto H, Uemura S, Ushio Y (1993) Ventriculolumbar Perfusion Of 3-[(4-amino-2-methyl-5-pyrimidinyl)methyl]-1-(chloroethyl)-1-nitrosourea hydrochloride. Neurosurgery 33: 817-823

[76] Kochi M, Takaki S, Kuratsu J-I, Seto H, Kitamura I, Ushio Y (1994) Neurotoxicity and pharmacokinetics of ventriculolumbar perfusion of methyl 6-[3-(2-chloroethyl)-3-nitrosoureido]-6-deoxy-alpha-D-gluco-pyranoside (MCNU) in dogs. Journal of Neuro-Oncology 19: 239-244

[77] Kohn F, Malkmus S, Brownson E, Rossi S, Yaksh T (1998) Fate of the predominant phospholipid component of DepoFoam ${ }^{\mathrm{TM}}$ drug delivery matrix after intrathecal administration of sustained-release encapsulated cytarabine in rats. Drug Delivery 5: 143-151

[78] Kooistra K, Rodriguez M, Powis G (1989) Toxicity of intrathecally administered cytotoxic drugs and their antitumor activity against an intrathecal Walker 256 carcinosarcoma model for meningeal carcinomatosis in the rat. Cancer Research 49: 977-982

[79] Kreuter J (2001) Nanoparticulate systems for brain delivery of drugs. Advanced Drug Delivery Reviews 47:

65-81

[80] Kuhl J, Doz F, Taylor R (2004) Embryonic tumors. In: Walker D, Perilongo G, Punt J, Taylor R (eds). Brain \& Spinal Tumors of Childhood. Arnold, London. pp. 314-330. 
[81] Lassaletta A, Lopez-Ibor B, Mateos E, Gonzalez-Vicent M, Perez-Martinez A, Sevilla J, Diaz M, Madero L (2009) Intrathecal liposomal cytarabine in children under 4 years with malignant brian tumours. Journal of NeuroOncology Epub ahead of print

[82] Levin V, Byrd D, Sikic B, Etiz B, Campbell J, Borcich J, Davis R (1985) Central Nervous System Toxicity and Cerebrospinal Fluid Pharmacokinetics of Intraventricularly Administered Bleomycin In Beagles. Cancer Research 45: $3810-3815$

[83] Levin V, Chamberlain M, Silver P, Rodriguez L, Prados M (1989) Phase I/II study of intraventricular and intrathecal ACNU for leptomeningeal neoplasia. Cancer Chemotherapy \& Pharmacology 23: 301-307

[84] Levin V, Edwards M, Gutin P, Vestnys P, Fulton D, Seager M, Wilson C (1984) Phase II evaluation of dibromodulcitol in the treatment of recurrent medulloblastoma, ependymoma and malignant astrocytoma. Journal of Neurosurgery 61: 1063-1068

[85] Lind M (1993) Pharmacokinetics of alkylating agents. Pharmacokinetics and Cancer Chemotherapy 17: 157-

[86] MacDonald D (1991) Neurologic complications of chemotherapy. Neurol Clin 9: 955-967

[87] Martindale (1999) The complete drug reference. Pharmaceutical Press, London.

[88] McKeran R, Firth G, Oliver S, Uttley D, O'Laoire S (1985) A potential application for the intracerebral injection of drugs entrapped within liposomes in the treatment of human cerebral gliomas. Journal of Neurology, Neurosurgery and Psychiatry 48: 1213-1219

[89] McVie J (1992) Teniposide (VM-26) in brain tumors. Seminars in Oncology 19: 85-88

[90] Morantz R, Kimler B, Vats T, Henderson S (1983) Leomycin and brain tumors. Journal of Neuro-Oncology 1: 249-255

[91] Nakagawa H, Maeda N, Tsuzuki T, Suzuki T, Hirayama A, Miyahara E, Wada K (2001) Intracavitary chemotherapy with 5-fluoro-2'-deox yuridine (FdUrd) in malignant brain tumors. Japan Journal of Clinical Oncology 31: 251-258

[92] Nakagawa H, Miyahara E, Suzuki T, Wada K, Tamura M, Fukushima Y (2005) Continuous intrathecal administration of 5-fluoro-2'-deoxyuridine for the treatment of neoplastic meningitis. Neurosurgery 57: 266-280 [93] Nakagawa H, Yamada M, Fukushima M, Ikenaka K (1999) Intrathecal 5-fluoro-2'-deoxyuridine (FdUrd) for the treatment of solid tumor neoplastic meningitis: an in vivo study. Cancer Chemotherapy \& Pharmacology 43: 247-

256

[94] Nakagawa H, Yamada M, Maeda N, Iwatsuki K, Hirayama Z, Ikenaka K (1999) Clinical trial of intrathecal administration of 5-fluoro-2'-deoxyuridine for treatment of meningeal dissemination of malignant brain tumors. Journal of Neuro-Oncology 45: 175-183

[95] National Cancer Institute www.nci.nih.gov.

[96] National Library of Medicine Special Information Services http:Ilchem.sis.nlm.nih.gov.

[97] Newlands E, Stevens M, Wedge S, Wheelhouse R, Brock C (1997) Temozolomide: a review of its discovery, chemical properties, pre-clinical development and clinical trials. Cancer Treatment Reviews 23: 35-61

[98] Nishio S, Morioka T, Takeshita I, Tadahisa S, Takanori I, Fujiwara S, Fukui M (1995) Chemotherapy for progressive pilocytic astrocytomas in the chiasmo-hypothalamic regions. Clinical Neurology and Neurosurgery 87: $300-$ 306

[99] Ochiai H, Pernell C, Archer G, Chewning T, McLendon R, Friedman H, Sampson J (2006) Treatment of neoplastic meningitis with intrathecal 9-Nitro-camptothecin. Neurol Med Chir (Tokyo) 46: 485-490

[100] Olivi A, Dundan L, Corden B, Lenartz D, Brem H (1993) Direct Delivery Of Platinum Based Neoplastics To The Central Nervous System : A Toxicity And Ultrastructural Study. Cancer Chemotherapy Pharmacology 31: 449-454 [101] Paal C, Erdelyi-Toth V, Pap E, Csaki C, Ferencz T, Schuler D, Borsi J (1994) Pharmacokinetic studies on Elobromol in children with brain tumors. Anti-Cancer Drugs 5: 539-547

[102] Pardridge W (1996) Brain Drug Delivery and Blood-Brain Barrier Transport. Drug Delivery 3: 99-115

[103] Pardridge W (2002) Drug and gene targeting to the brain with molecular Trojan horses. Nature Reviews Drug Discovery 1: 131-139

[104] Phillips P, Than T, Cork L, Hilton J, Carson B, Colvin O, Grochow L (1992) Intrathecal 4-

hydroperoxycyclophosphamide: Neurotoxicity, cerebrospinal fluid pharmacokinetics, and antitumor activity in a rabbit model of VX2 leptomeningeal carcinomatosis. Cancer Research 52: 6168-6174

[105] Read T-A, Thorsen F, Bjerkvig R (2002) Localised delivery of therapeutic agents to CNS malignancies; old and new approaches. Current Pharmaceutical Technology 3: 257-273

[106] Rhone Poulenc Rorer (1999) Information from Medical Information Department. West Malling, Kent.

[107] Riccardi R, Riccardi A, Di Rocco C, Carelli G, Tartaglia R, Lasorella A, Servidei T, Mastrangelo R (1992)

Cerebrospinal fluid pharmacokinetics of carboplatin in children with brain tumors. Cancer Chemotherapy and Pharmacology 30: 21-24

[108] Ruggiero A, Conter V, Milani M, Biagi E, Lazzareschi I, Sparano P, Riccardi R (2001) Intrathecal chemotherapy with antineoplastic agents in children. Paediatric Drugs 3: 237-246

[109] Rutkowski S, Bode U, Deinlein F, Ottensmeier H, Warmuth-Metz M, Soerensen N, Graf N, Emser A, Pietsch T, Wolff J, Korkmann R, Kuehl J (2005) Treatment of early childhood medulloblastoma by postoperative chemotherapy alone. New England Journal of Medicine 352: 978-986 
[110] Rutkowski S, Von Hoff K, Emser A, Garre ML, Walker D, Grundy R, Dhall G, Finlay J, Grill J (2008) Prognostic factors and survival of young children with medulloblastoma: An international meta-analysis. NeuroOncology 10: 437

[111] Sampson J, Archer G, Villavicencio A, McLendon R, Friedman A, Bishop W, Bigner D, Friedman H (1999) Treatment of neoplastic meningitis with intrathecal temozolomide. Clinical Cancer Research 5: 1183-1188

[112] Savaraj N, Feun L, Lu K, Gray K, Wang C, Loo T (1992) Pharmacology of intrathecal VP-16-213 in dogs. Journal of Neuro-Oncology 13: 211-215

[113] Savas A, Erdem A, Tun K, Kanpolat Y (2000) Fatal toxic effect of bleomycin in brain tissue after intracystic chemotherapy for a craniopharyngioma: Case report. Neurosurgery 46: 213-217

[114] Schmandt S, Kuhl J (1998) Chemotherapy as prophylaxis and treatment of meningosis in children less than 3 years of age with medulloblastoma. Journal of Neuro-Oncology 38: 187-192

[115] Schold Jr S, Mahaley Jr M, Vick N, Friedman H, Burger P, DeLong E, Albright Jr R, Bullard D, Khandekar D, Cairncross J, Macdonald D, Falletta J (1987) Phase II diaziquone-based chemotherapy trials in patients with anaplastic supratentorial astrocytic neoplasms. Journal of Clinical Oncology 5: 464-471

[116] Schuler D, Somlo P, Borsi J, Paraicz E, Revesz T, Kardos G, Koos R (1988) New drug combination for the treatment of relapsed brain tumors in children. Pediatric Hematology \& Oncology 5: 153-156

[117] Schuler D, Somlo P, Koos R, Kalmanchey R, Paraicz E (1992) Treatment of malignant scala posterior brain tumors in children: the chemotherapy of relapsed medulloblastoma with a dibromdulcitol-containing drug regime and pharmacokinetic studies of dibromdulcitol in children. Medical \& Pediatric Oncology 20: 312-314

[118] Screnci D, McKeage M, Galettis P, Hambley T, Palmer B, Baguley B (2000) Relationships between hydrophobicity, reactivity, accumulation and peripheral nerve toxicity of a series of platinum drugs. British Journal of Cancer 82: 966-972

[119] Selby G, Upchurch C, Townsend J, Eyre H (1994) A phase II evaluation of fazarabine in high-grade gliomas: a Southwest Oncology Group study. Cancer Chemotherapy \& Pharmacology 34: 179-180

[120] Slavc I, Schuller E, Czech T, Hainfellner J, Seidl R, Dieckmann K (1998) Intrathecal mafosfamide therapy for paediatric brain tumors with meningeal dissemination. Journal of Neuro-Oncology 38: 213-218

[121] Slave I, Schuller E, Falger J, Gunes M, Pillwein K, Czech T, Dietrich W, Rossler K, Dieckmann K, Prayer D, Hainfellner J (2003) Feasibility of long-tem intraventricular therapy with mafosfamide $(n=26)$ and etoposide $(n=11)$ : Experience in 26 children with disseminated malignant brain tumors. Journal of Neuro-Oncology 64: 239-247 [122] SmithKline Beecham Pharmaceuticals (1999) Information from Medical Information Department. Welwyn Garden City.

[123] Stempien L, Tsai T (2000) Intrathecal baclofen pump use for spasticity: a clinical survey. American Journal of Physical Medicine \& Rehabilitation 79: 536-541

[124] Stevens M, Newlands E (1993) From triazines and triazines to temozolomide. European Journal of Cancer 29a: $1045-1047$

[125] Stiller C, Bleyer W (2004) Epidemiology. In: Walker D, Perilongo G, Punt J, Taylor R (eds). Brain \& Spinal Tumors of Childhood. Arnold, London. pp. 35-49.

[126] Taylor E (2002) The impact of efflux transporters in the brain on the development of drugs for CNS disorders. Clinical Pharmacokinetics 41: 81-92

[127] Taylor S (1994) New agents in the treatment of primary brain tumors. Journal of Neuro-Oncology 20: 141-153

[128] Tomlinson F, Lihou M, Smith P (1991) Comparison of in vitro activity of epipodophyllotoxins with other chemotherapeutic agents in human medulloblastomas. British Journal of Cancer 64: 1051-1059

[129] Tsuboi K, Yoshii Y, Hyodo A, Takada K, Nose T (1995) Leukoencephalopathy associated with intra-arterial ACNU in patients with gliomas. Journal of Neuro-Oncology 23: 223-231

[130] Tuxen M, Hansen S (1994) Neurotoxicity secondary to antineoplastic drugs. Cancer Treatment Reviews 20: 191-214

[131] Ushio Y, Kochi M (1998) Intrathecal perfusion chemotherapy with ACNU against subarachnoid dissemination of glioma in children. Int J Pediat Hem Oncol 5: 55-56

[132] Ushio Y, Kochi M, Kitamura I, Kuratsu J (1998) Ventriculolumbar perfusion of 3-[(4-amino-2-methyl-5pyrimidinyl)-methyl]-1-(2-cloroethyl)-1-nitrosourea hydrochloride for subarachnoid dissemination of gliomas. Journal of Neuro-Oncology 38: 207-212

[133] van der Gaast A, Sonneveld P, Mans D, Splinter T (1992) Intrathecal administration of etoposide in the treatment of malignant meningitis: feasibility and pharmacokinetic data. Cancer Chemotherapy \& Pharmacology 29: 335-337

[134] van der Graaf W, Haaxma-Reiche H, Burghouts J, Postmus P (1993) Teniposide for meningeal carcinomatosis of small cell lung cancer. Lung Cancer 10: 247-249

[135] Vassal G, Boland I, Santos A, Bissery M, Terrier-Lacombe M, Morizet J, Sainte-Rose C, Lellouch-Tubiana A, Kalifa C, Gouyette A (1997) Potent Therapeutic Activity of Irinotecan (CPT-11) and its Schedule Dependency in Medulloblastoma Xenografts in Nude Mice. International Journal of Cancer 73: 156-163

[136] Vassal G, Boland I, Terrier-Lacombe M, Watson A, Margison G, Venuat A, Morizet J, Parker F, Lacroix C, Lellouch-Tubiana A, Pierre-Kahn A, Poullain M, Gouyette A (1998) Activity of Fotemustine in Medulloblastoma and Malignant Glioma Xenografts in Relation to $O^{6}$-Alkylguanine-DNA Alkyltransferase and Alkylpurine-DNA $N$ -

Glycosylase Activity. Clinical Cancer Research 4: 463-468 
[137] Vassal G, Pondarre C, Boland I, Cappelli C, Santos A, Thomas C, Lucchi E, Imadalou K, Pein F, Morizet J, Gouyette A (1998) Preclinical development of camptothecin derivatives and clinical trials in pediatric oncology. Biochimie 80: 271-280

[138] Vassal G, Terrier-Lacombe M-J, Bissery M, Venuat A, Gyergyay F, Benard J, Morizet J, Boland I, Ardouin P, Bressac-de-Paillerets B, Gouyette A (1996) Therapeutic activity of CPT-11, a DNA-topoisomerase I inhibitor, against peripheral primitive neuroectodermal tumour and neuroblastoma xenografts. British Journal of Cancer 75: 537-545

[139] Walker D, Wilne S (2005) Treatment of medulloblastoma in young children. Lancet Oncology 6: 541-542

[140] Wang P, Frazier J, Brem H (2002) Local drug delivery to the brain. Adv Drug Del 54: 987-1013

[141] Ward H (1978) Central nervous system tumors of childhood treated with CCNU, vincristine and radiation. Medical \& Pediatric Oncology 4: 315-320

[142] Watterson J, Toogood I, Nieder M, Morse M, Frierdich S, Lee Y, Moertel C, Priest J (1994) Excessive spinal cord toxicity from intensive central nervous system-directed therapies. Cancer 74: 3034-3041

[143] Weiss R, Issell B (1982) The nitrosoureas: carmustine (BCNU) and lomustine (CCNU). Cancer Treatment Reviews 9: 313-330

[144] Yamada M, Nakagawa H, Fukushima M, Shimizu K, Hayakawa T, Ikenaka K (1998) In vitro study on intrathecal use of 5-fluoro-2'-deoxyuridine (FdUrd) for meningeal dissemination of malignant brain tumors. Journal of Neuro-Oncology 37: 115-121

[145] Yamasaki T, Kikuchi H, Yamashita J, Asato R, Fujita M (1989) Primary spinal intramedullary malignant melanoma: case report. Neurosurgery 25: 117-121

[146] Yamashima T, Yamashita J, Shoin K (1990) Neurotoxicity of local administration of two nitrosoureas in malignant gliomas. Neurosurgery 26: 794-800

[147] Yoshida T, Beuls E, Shimizu K, Koulousakis A, Sturm V (1992) Intrathecal chemotherapy with ACNU for meningeal gliomatosis. British Journal of Cancer 66: 999-1004

[148] Yoshida T, Shimizu K, Koulousakis A, Sturm V (1992) Intrathecal Chemotherapy With ACNU In A Meningeal Gliomatosis Rat Model. Journal Of Neurosurgery 77: 778-782

[149] Yoshimura J, Nishiyama K, Mori H, Takahashi H, Fujii Y (2008) Intrathecal chemotherapy for refractory disseminated medulloblastoma. Child's Nervous System 24: 581-585

[150] Zimm S, Collins J, Curt G, O'Neill D, Poplack D (1984) Cerebrospinal fluid pharmacokinetics of intraventricular and intravenous aziridinylbenzoquinone. Cancer Research 44: 1698-1701

[151] Zimm S, Collins J, Miser J, Chatterji D, Poplack D (1984) Cytosine arabinoside cerebrospinal fluid kinetics. Clinical Pharmacological Therapeutics 35: 826-830 
Table 1: Summary of ideal clinical, biological and physicochemical / pharmaceutical properties used to justify selection or rejection of drugs.

\begin{tabular}{|c|}
\hline \multirow{2}{*}{$\begin{array}{l}\text { Property Required } \\
\text { ClinicalNon-irritant } \\
\text { Neurotoxicity low or absent } \\
\text { Evidence of tumour sensitivity }\end{array}$} \\
\hline \\
\hline $\begin{array}{l}\text { Biological } \\
\text { CSF transport system absent } \\
\text { Cell cycle non-specific agent }\end{array}$ \\
\hline $\begin{array}{l}\text { Physicochemical \& pharmaceutical } \\
\text { Active in CSF }\end{array}$ \\
\hline $\begin{array}{l}\text { Hydrophilic and/or ionised at CSF pH } \\
\text { therefore low membrane permeability (to } \\
\text { minimise diffusion out of CSF) } \\
\text { Molecular Size ( } 700 \mathrm{Da} \text { ) } \\
\text { Suitable formulation readily available }\end{array}$ \\
\hline
\end{tabular}


Table 2: List of chemotherapy drugs considered with selection / rejection status and rejection justification

Table 2a - Rejected chemotherapy agents plus justification

\begin{tabular}{|c|c|c|c|c|c|c|}
\hline Irritant & $\begin{array}{l}\text { No tumour } \\
\text { activity }\end{array}$ & No information & $\begin{array}{l}\text { Requires } \\
\text { activation }\end{array}$ & Neurotoxic & $\begin{array}{l}\text { Neurotoxic and } \\
\text { irritant }\end{array}$ & $\begin{array}{l}\text { Neurotoxic via } \\
\text { IT route }\end{array}$ \\
\hline Aclarubicin & Carbetimer & $\begin{array}{l}\text { AG-337 } \\
\text { (Noltatrexed) }\end{array}$ & Capecitabine & Acivicin & Altretamine & Doxorubicin \\
\hline Amsacrine & Mitoguazone & Amonafide & Cyclophosphamide & Asparaginase & Chlorambucil & Melphalan \\
\hline Azathioprine & & Amrubicin & Mitomycin & Carmofur & & Mitozantrone \\
\hline Dactinomycin & & Azacitidine & Procarbazine & Cisplatin & & $* *$ Fluorouracil \\
\hline Daunorubicin & & Bendamustine & Trofosfamide & Cladribine & & \\
\hline Epirubicin & & Bisantrene & *Thiotepa & Docetaxel & & \\
\hline Idarubicin & & Caracemide & & Doxifluridine & & \\
\hline $\begin{array}{l}\text { Mustine } \\
\text { (Mechlorethamine) }\end{array}$ & & Carboquone & & Fludarabine & & \\
\hline Paclitaxel & & $\begin{array}{l}\text { Chlorozotocin } \\
\text { (DCNU) }\end{array}$ & & Fotemustine & & \\
\hline Pirarubicin & & Chromomycin & & Gemcitabine & & \\
\hline Piroxantrone & & Clofarabine & & Hydroxyurea & & \\
\hline Plicamycin & & Crisnatol & & Ifosfamide & & \\
\hline Streptozocin & & Decitabine & & Methotrexate & & \\
\hline Valrubicin & & Echinomycin & & Mitotane & & \\
\hline \multirow[t]{11}{*}{ Zorubicin } & & Edatrexate & & Oxaliplatin & & \\
\hline & & Enloplatin & & Pentostatin & & \\
\hline & & Enocitabine & & Sparfosic acid & & \\
\hline & & Estramustine & & Spiromustine & & \\
\hline & & Homoharringtonine & & Suramin & & \\
\hline & & Ilmofosine & & Tegafur & & \\
\hline & & Improsulfan & & Vinblastine & & \\
\hline & & $\begin{array}{l}\text { JM-216 } \\
\text { (Satraplatin) }\end{array}$ & & Vincristine & & \\
\hline & & Lobaplatin & & Vindesine & & \\
\hline & & Miboplatin & & Vinorelbine & & \\
\hline & & Mitobronitol & & & & \\
\hline
\end{tabular}




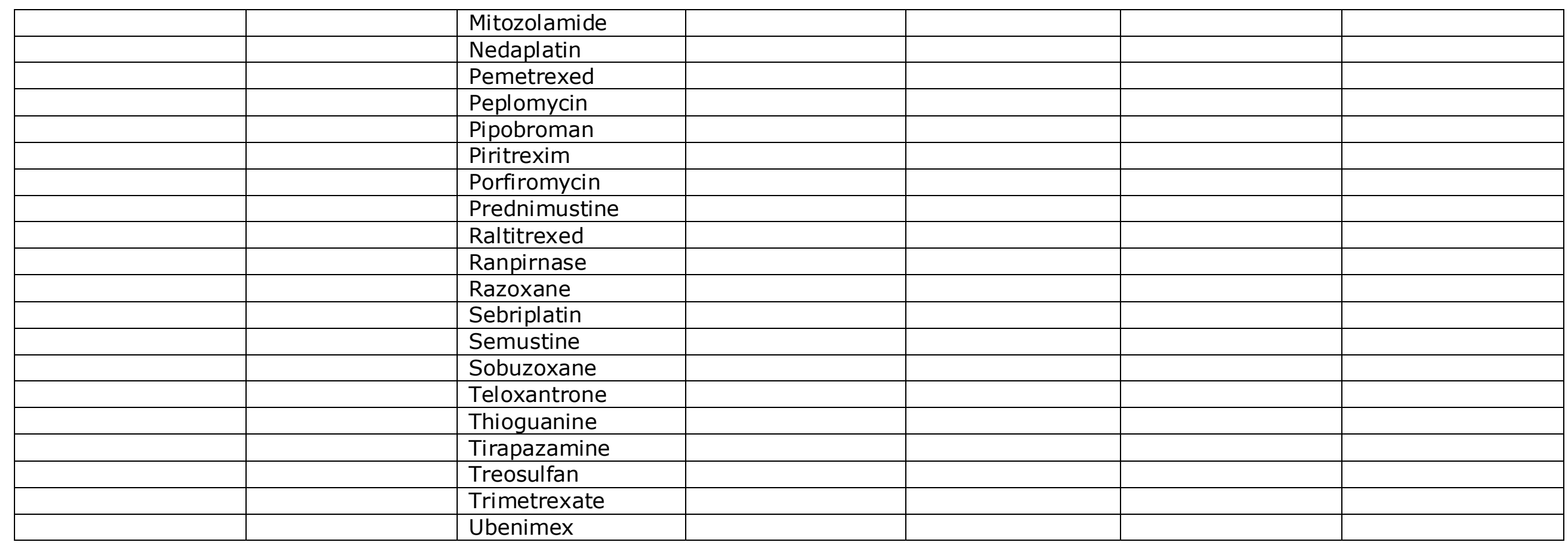

* Systemic administration delivers concentration to IT route

** Also irritant 


\begin{tabular}{|c|c|c|}
\hline 1. Carboplatin & Selection & Table 3 \\
\hline 2. Cytarabine & Selection & Table 3 \\
\hline 3. Diaziquone & Selection & Table 3 \\
\hline 4. Etoposide & Selection & Table 3 \\
\hline 5. Floxuridine (FdUrd) & Selection & Table 3 \\
\hline 6. 4-hydroperoxycyclophosphamide & Selection & Table 3 \\
\hline 7. Mafosfamide & Selection & Table 3 \\
\hline 8. Mercaptopurine & Selection & Table 3 \\
\hline 9. Nimustine (ACNU) & Selection & Table 3 \\
\hline 10. Temozolomide & Selection & Table 3 \\
\hline 11. Topotecan & Selection & Table 3 \\
\hline 12. Eflornithine & Selection & Table 4 \\
\hline 13. Mitolactol (Dibromodulcitol) & Selection & Table 4 \\
\hline 14. Didemnin B & Selection & Table 4 \\
\hline 15. Irinotecan & Selection & Table 4 \\
\hline 16. Lomustine (CCNU) & Selection & Table 4 \\
\hline 17. Lonidamine & Selection & Table 4 \\
\hline 18. Menogaril & Selection & Table 4 \\
\hline 19. Tauromustine & Selection & Table 4 \\
\hline 20. Teniposide & Selection & Table 4 \\
\hline 21. Bleomycin & Rejection & Table 5 - neurotoxic when given IT \\
\hline 22. Busulphan & Selection & Table 5 \\
\hline 23. Carmustine (BCNU) & Selection & Table 5 \\
\hline 24. Dacarbazine & Selection & Table 5 \\
\hline 25. Fazarabine & Selection & Table 5 \\
\hline 26. Ranimustine (MCNU) & Selection & Table 5 \\
\hline 27. Zinostatin & Selection & Table 5 \\
\hline
\end{tabular}


Table 3: Drugs graded by eligibility for trial by intrathecal administration for medulloblastoma

\section{Legend}

OWPC $=$ octanol/water partition coefficient $>0$ = lipophilic; $<0=$ hydrophilic (different values obtained from different references)

pKa $=$ dissociation constant. pKa $<5.3$ or $>9.3$ indicate an ionisation of $>99 \%$ at $\mathrm{CSF}$ pH of 7.3

$\mathrm{MW}=$ molecular weightIV $=$ intraventricular. $\mathrm{IL}=$ intralumbar. IC $=$ intracavity/tumour. IT $=$ intrathecal

RMM - refractory meningeal malignancy, MB = medulloblastoma, LMC = leptomeningeal carcinomatosis, LMM = leptopmeningeal meningitis, NM = neoplastic meningitis3a

\section{Agents under trial.}

\begin{tabular}{|c|c|c|c|c|c|c|c|c|}
\hline DRUG & OWPC & pKa & $M W$ & $\begin{array}{l}\text { Evidence of } \\
\text { medulloblastoma (MB / } \\
\text { PNET) chemosensitivity }\end{array}$ & Evidence of IT use. & $\begin{array}{l}\text { Cell cycle } \\
\text { phase } \\
\text { specificity }\end{array}$ & Comments & Refs \\
\hline $\begin{array}{l}\text { Cytarabine } \\
\text { (liposomal } \\
\text { formulation) }\end{array}$ & -2.46 & 4.3 & 243 & $\begin{array}{l}\text { Evidence of MB sensitivity, } \\
\text { Randomised Clinical Trial in NM } \\
\text { had } 13 / 18 \text { responders with IT } \\
\text { liposomal v } 3 / 17 \text { with free } \\
\text { cytarabine. }\end{array}$ & $\begin{array}{l}\text { Licensed in } \\
\text { lymphomatous } \\
\text { meningitis in adults. } \\
\text { Phase } 1 \text { trial in children } \\
\text { with NM established } \\
\text { maximum tolerated } \\
\text { dose and showed } \\
\text { benefit in } 8 / 14 \text { pts. } \\
\text { Phase } 2 \text { trial is in } \\
\text { development. }\end{array}$ & S phase & $\begin{array}{l}\text { Neurotoxic in standard } \\
\text { formulation. Liposomal } \\
\text { preparation used for IT is less } \\
\text { toxic and half life in CSF is } \\
\text { prolonged up to } 40 \text { times, } \\
\text { though is less in children than } \\
\text { adults. Dexametasone is } \\
\text { required to avoid } \\
\text { arachnoiditis. }\end{array}$ & $\begin{array}{l}{[1,11,20,} \\
27,32,33, \\
36,37,42, \\
44,64,66, \\
68-70,73, \\
77,78,87 \\
95,96,130, \\
142]\end{array}$ \\
\hline Mafosfamide & $0.56,-2.11$ & & 401 & $\begin{array}{l}\text { MB, PNET, ependymoma pts, } \\
\text { LMC -rabbit only }\end{array}$ & $\begin{array}{l}\text { IV -non-human } \\
\text { primate, IV -rabbit. } \\
\text { Phase } 1 \text { study in } \\
\text { patients with RMM, IV+ } \\
\text { IL paediatric patients } \\
\text { showed good effect + } \\
\text { minimal toxicity. Phase } \\
1 \text { study has } \\
\text { determined maximum } \\
\text { tolerated dose in } \\
\text { children <3yrs with } \\
\text { newly diagnosed } \\
\text { embryonal tumours - } \\
\text { phase } 2 \text { trial in } \\
\text { progress }\end{array}$ & non & $\begin{array}{l}\text { Cyclophosphamide derivative, } \\
\text { undergoes spontaneous } \\
\text { hydrolysis to active species }\end{array}$ & $\begin{array}{l}{[1,17,21,} \\
42,87,95, \\
96,104,120, \\
121,128]\end{array}$ \\
\hline
\end{tabular}


Table 3b: Agents suitable for clinical trial.

\begin{tabular}{|c|c|c|c|c|c|c|c|c|}
\hline DRUG & OWPC & pKa & $M W$ & $\begin{array}{l}\text { Evidence of } \\
\text { medulloblastoma (MB / } \\
\text { PNET) chemosensitivity }\end{array}$ & Evidence of IT use. & $\begin{array}{l}\text { Cell cycle } \\
\text { phase } \\
\text { specificity }\end{array}$ & Comments & Refs \\
\hline Carboplatin & -0.46 & & 371 & $\begin{array}{l}\text { High grade gliomas, MB, PNET, } \\
\text { ependymoblastoma }\end{array}$ & $\begin{array}{l}\text { IT in rats showed this } \\
\text { to be the least } \\
\text { neurotoxic of the } \\
\text { platins. Neurotoxicity } \\
\text { not seen until lethal } \\
\text { dose }\end{array}$ & non & & $\begin{array}{l}39,41, \\
95,96, \\
100,107 \\
118,127]\end{array}$ \\
\hline Etoposide & 0.6 & 9.7 & 589 & 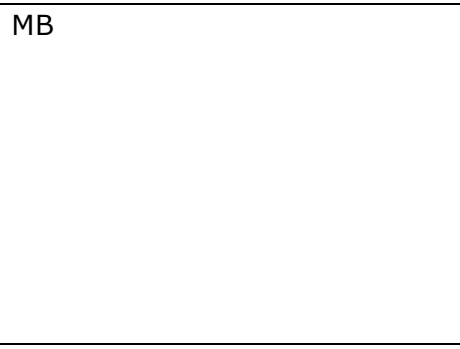 & $\begin{array}{l}\text { IV -dogs, humans IV - } \\
\text { metastatic MB, } \\
\text { malignant meningitis. } \\
\text { Used IV in paediatric } \\
\text { patients with good } \\
\text { effect + minimal } \\
\text { toxicity }\end{array}$ & Late S, G2 & $\begin{array}{l}\text { Poor CSF distribution following } \\
\text { IV administration, possibly due } \\
\text { to rapid CSF clearance due to } \\
\text { lipophilicity and/or efflux by P- } \\
\text { glycoprotein and MDR- } \\
\text { associated protein } 1 . \\
\text { Possible problem with IL route } \\
\text { due to concerns of drug and } \\
\text { preservatives causing spinal } \\
\text { cord damage. }\end{array}$ & $\begin{array}{l}1,40,42, \\
87,95,96, \\
112,114, \\
121,126, \\
128,133]\end{array}$ \\
\hline Nimustine (ACNU) & $\begin{array}{l}0.39 \\
\text { Water + } \\
\text { lipid } \\
\text { soluble }\end{array}$ & & 309 & $\begin{array}{l}\text { Pilocytic astrocytoma, } \\
\text { meningeal spread of MB, PNET, } \\
\text { glioblastoma, anaplastic } \\
\text { glioma. }\end{array}$ & $\begin{array}{l}\text { MC - rat, dog, IV in } \\
\text { meningeal spread of } \\
\text { MB, PNET, } \\
\text { glioblastoma, } \\
\text { anaplastic glioma, A } \\
\text { phase } 1 / 11 \text { study } \\
\text { involving IV/IL/ } \\
\text { IT admin in } 21 \text { patients } \\
\text { (including children) } \\
\text { with refractory } \\
\text { disseminated MB } \\
\text { showed efficacy in } \\
\text { some patients }\end{array}$ & non & $\begin{array}{l}\text { When given IV, needed infusion } \\
\text { - bolus did not give adequate } \\
\text { subarachnoid spread as CSF } \\
\text { half-life very } \\
\text { short(approximately } 27 \mathrm{~min} \text { ) } \\
\text { High priority for future study in } \\
\text { appropriate delivery system }\end{array}$ & $\begin{array}{l}{[6,42,61,} \\
63,74-76, \\
83,87,95, \\
96,98, \\
129,131, \\
132,146- \\
149]\end{array}$ \\
\hline
\end{tabular}


Table 3c: Drugs requiring further investigation before clinical trial.

\begin{tabular}{|c|c|c|c|c|c|c|c|c|}
\hline DRUG & OWPC & $p K a$ & $M W$ & $\begin{array}{l}\text { Evidence of } \\
\text { medulloblastoma (MB / } \\
\text { PNET) chemosensitivity }\end{array}$ & Evidence of IT use. & $\begin{array}{l}\text { Cell cycle } \\
\text { phase } \\
\text { specificity }\end{array}$ & Comments & Refs \\
\hline Floxuridine (FdUrd) & -1.16 & 7.44 & 246 & $\begin{array}{l}\text { MB, glioma LMC -animal + } \\
\text { humans, NM }\end{array}$ & $\begin{array}{l}\text { LMC, NM by continuous } \\
\text { IT infusion. } \\
\text { Intracavitary } \\
\text { administration may be } \\
\text { useful in small volume } \\
\text { malignant brain } \\
\text { tumours }\end{array}$ & & & $\begin{array}{l}{[1,42,87} \\
91-96,144]\end{array}$ \\
\hline $\begin{array}{l}\text { 4-hydroperoxy- } \\
\text { cyclophosphamide }\end{array}$ & & & 293 & $\begin{array}{l}\text { Promising phase } 1 \text { trial IT in } \\
\text { MB, PNET }\end{array}$ & $\begin{array}{l}\text { Promising phase } 1 \text { trial } \\
\text { IT in MB, PNET. IV } \\
\text { administration in } \\
\text { monkeys }\end{array}$ & non & & $\begin{array}{l}{[7,52,95,} \\
96]\end{array}$ \\
\hline
\end{tabular}


3d: Drugs requiring further investigation, lower priority.

\begin{tabular}{|c|c|c|c|c|c|c|c|c|}
\hline DRUG & OWPC & pKa & $M W$ & $\begin{array}{l}\text { Evidence of } \\
\text { medulloblastoma (MB / } \\
\text { PNET) chemosensitivity }\end{array}$ & Evidence of IT use. & $\begin{array}{l}\text { Cell cycle } \\
\text { phase } \\
\text { specificity }\end{array}$ & Comments & Refs \\
\hline Diaziquone & -0.758 & $\begin{array}{l}\text { low } \\
\text { ionisation } \\
\text { at } \\
\text { physiologic } \\
\text { al pH }\end{array}$ & 364 & $\begin{array}{l}\text { 9L rat brain tumour, LMC, } \\
\text { GBM, AA, paed brain tumours, } \\
\text { RMM, recurrent glioma - phase } \\
11 \text { studies, MB xenograft in } \\
\text { mice }\end{array}$ & $\begin{array}{l}\text { Rat, IV-non-human } \\
\text { primate studies, } \\
\text { Human patients } \\
\text { including children with } \\
\text { RMM - phase } 1 / 11 \\
\text { studies - good } \\
\text { response }\end{array}$ & & $\begin{array}{l}\text { Low aqueous solubility has } \\
\text { caused formulation problems. } \\
\text { Drug shows high rate of } \\
\text { clearance from CSF }\end{array}$ & $\begin{array}{l}{[1,13,14,} \\
21,31,42, \\
43,47,62, \\
71,78,87, \\
95,96,115, \\
127,150]\end{array}$ \\
\hline Mercaptopurine & 0.01 & $7.77,11.17$ & 170 & LMD of ALL & $\begin{array}{l}\text { IV - monkey then } \\
\text { children }\end{array}$ & S - phase & $\begin{array}{l}\text { Cleared from CSF at } \\
0.63 \mathrm{ml} / \mathrm{min} \text { (bulk flow } \\
0.4 \mathrm{ml} / \mathrm{min} \text { ) suggesting an } \\
\text { additional mechanism of } \\
\text { elimination - possibly efflux by } \\
\text { MDR-associated protein } 1 \text { and } \\
\text { monocarboxylic acid } \\
\text { transporters }\end{array}$ & $\begin{array}{l}(25,59,60 \\
91,105,107)\end{array}$ \\
\hline Rubitecan & & & 393 & $\begin{array}{l}\text { safe \& effective in rat model } \\
\text { against human GBM xenograft } \\
\text { NM }\end{array}$ & $\begin{array}{l}\text { IT safe } \& \text { effective in } \\
\text { rat model of GBM NM }\end{array}$ & S-phase & & \\
\hline Topotecan & $\begin{array}{l}0.83,- \\
0.3\end{array}$ & $6.35,10.1$ & 458 & $\begin{array}{l}\text { ependymoma, MB, high grade } \\
\text { glioma xenografts }\end{array}$ & $\begin{array}{l}\text { IV non-human primate. } \\
\text { IV \& IL to children \& } \\
\text { adults with refractory } \\
\text { neoplastic meningitis. } \\
\text { Phase } 2 \text { study } \\
\text { underway. }\end{array}$ & S-phase & $\begin{array}{l}\text { Chemical arachnoiditis dose } \\
\text { limiting toxicity. Rapid } \\
\text { elimination from CSF. Novel } \\
\text { mechanism of action }\end{array}$ & $\begin{array}{l}{[1,10,18-} \\
21,87,95 \\
96,99,122 \\
137]\end{array}$ \\
\hline
\end{tabular}


Table 3e: Drug with insufficient information to grade

\begin{tabular}{|c|c|c|c|c|c|c|c|c|}
\hline DRUG & OWPC & pKa & $M W$ & $\begin{array}{l}\text { Evidence of } \\
\text { medulloblastoma (MB / } \\
\text { PNET) chemosensitivity }\end{array}$ & Evidence of IT use. & $\begin{array}{l}\text { Cell cycle } \\
\text { phase } \\
\text { specificity }\end{array}$ & Comments & Refs \\
\hline Temozolomide & $\begin{array}{l}-0.58,- \\
1.32\end{array}$ & & 194 & $\begin{array}{l}\text { CNS tumour xenografts, NM } \\
\text { Phase } 2 \text { studies in MB, } \\
\text { astrocytoma, glioma, GBM }\end{array}$ & $\begin{array}{l}\text { microcrystalline prep } \\
\text { with increased } \\
\text { solubility - used IT in } \\
\text { rats with NM + malig } \\
\text { glioma sub arachnoid } \\
\text { xenografts }\end{array}$ & & $\begin{array}{l}\text { Spontaneous conversion to } \\
\text { active mitomycin in physiological } \\
\text { conditions. Highly insoluble in } \\
\text { aqueous solution, } \\
\text { microcrystalline form increased } \\
\text { solubility }\end{array}$ & $\begin{array}{l}{[1,42,50,} \\
87,95-97, \\
111,124]\end{array}$ \\
\hline
\end{tabular}


Table 4: Drugs with documented activity in the relevant tumour types but no information on intrathecal use.

\begin{tabular}{|c|c|c|c|c|c|c|c|c|c|}
\hline DRUG & OWPC & pKa & MW & $\begin{array}{l}\text { Evidence of tumour } \\
\text { sensitivity }\end{array}$ & $\begin{array}{l}\text { Previous IT } \\
\text { use. }\end{array}$ & $\begin{array}{l}\text { Cell cycle } \\
\text { phase } \\
\text { specific }\end{array}$ & $\begin{array}{l}\text { Neuro- } \\
\text { toxicity }\end{array}$ & Comments & Refs \\
\hline Didemnin B & 3.173 & & 1112 & $\begin{array}{l}\text { Some response seen in GBM } \\
\text { and progressive high grade } \\
\text { gliomas }\end{array}$ & & & & $\begin{array}{l}\text { Natural marine product, antiviral } \\
\text { and antineoplastic activity }\end{array}$ & {$[95,96,127]$} \\
\hline Eflornithine & -2.945 & & 182 & $\begin{array}{l}\text { In combination with } \\
\text { mitoguazone, response seen } \\
\text { in anaplastic astrocytoma and } \\
\text { GBM }\end{array}$ & & & & & {$[95,96,127]$} \\
\hline Irinotecan & $\begin{array}{l}0.03(\mathrm{pH} 1-6) \\
0.095 \text { (pH9-12). } \\
\text { At pH7-slightly } \\
\text { more lipophilic } \\
\text { but likely to be } \\
\text { more hydrophilic } \\
\text { than lipophilic }\end{array}$ & $\begin{array}{l}1.07 \\
7.89\end{array}$ & 677 & $\begin{array}{l}\text { peripheral PNET, } \\
\text { neuroblastoma xenografts, } \\
\text { MB, glioma, ependymoma } \\
\text { xenografts. GBM, } \\
\text { ependymo ma, MB (animal } \\
\text { models), some evidence of } \\
\text { activity in recurrent glioma }\end{array}$ & & S-phase & & $\begin{array}{l}\text { Requires metabolism by } \\
\text { carboxylesterase in liver \& tissues } \\
\text { to SN-38 to provide most of it's } \\
\text { cytotoxic activity - it is not known if } \\
\text { this would occur in the CSF }\end{array}$ & $\begin{array}{l}{[28,59,87,95,96,} \\
106,135,138]\end{array}$ \\
\hline Lomustine (CCNU) & 2.629 & & 234 & MB, glioma & & non & & $\begin{array}{l}\text { Alkylating and carbamoylating } \\
\text { agent }\end{array}$ & $\begin{array}{l}{[10,42,62,85,87,} \\
95,96,114,141]\end{array}$ \\
\hline Lonidamine & 4.407 & & 321 & $\begin{array}{l}\text { Prolongation of survival + } \\
\text { rate of } 1 \text { year survivors ( } 62 \mathrm{v} \\
35 \% \text { ) supratentorial glioma }\end{array}$ & & & $\begin{array}{l}\text { Drowsiness, } \\
\text { weakness }\end{array}$ & $\begin{array}{l}\text { Inhibits lactate production causing } \\
\text { interference with energy } \\
\text { metabolism of cancer cells }\end{array}$ & {$[87,95,96,127]$} \\
\hline Menogaril & 1.066 & & 542 & $\begin{array}{l}\text { High grade glioma, phase } 1 \\
\text { and } 11 \text { trials give conflicting } \\
\text { results }\end{array}$ & & ? non & & $\begin{array}{l}\text { Anthracycline, therefore likely to be } \\
\text { irritant }\end{array}$ & $\begin{array}{l}{[42,87,95,96,} \\
127]\end{array}$ \\
\hline $\begin{array}{l}\text { Mitolactol } \\
\text { (Dibromodulcitol) }\end{array}$ & -0.426 & & 308 & $\begin{array}{l}\text { MB, PNET, ependymoma - } \\
\text { single agent, moderate effect }\end{array}$ & & & & $\begin{array}{l}\text { long duration of presence in CSF } \\
\text { with a half life of around } 24 \text { hours }\end{array}$ & $\begin{array}{l}{[39,42,84,87,95,} \\
96,101,116,117]\end{array}$ \\
\hline Teniposide & $\begin{array}{l}-0.03 \text { (estimated } \\
\text { by calculation } \\
\text { with low } \\
\text { confidence } \\
\text { probably higher) }\end{array}$ & 10.13 & 657 & MB in cell culture & & & As etoposide & efflux by P-glycoprotein & $\begin{array}{l}{[39,42,87,89,95,} \\
96,128,134]\end{array}$ \\
\hline Tauromustine & -0.299 & & 287 & $\begin{array}{l}\text { AA, glioblastoma, clinical } \\
\text { improvement seen in } 19 / 46 \\
\text { patients }\end{array}$ & & ? non & & & $(59,60,71)$ \\
\hline
\end{tabular}


Table 5: Drugs tested by the intrathecal route (some animal, some human) with mixed reports of toxicity and efficacy:

\begin{tabular}{|c|c|c|c|c|c|c|c|c|c|}
\hline DRUG & OWPC & $p K a$ & $M W$ & $\begin{array}{c}\text { Evidence of } \\
\text { tumour } \\
\text { sensitivity }\end{array}$ & $\begin{array}{c}\text { Previous IT } \\
\text { use } \\
\text { IV }=\text { intra- }\end{array}$ & $\begin{array}{l}\text { Cell cycle } \\
\text { phase } \\
\text { specific }\end{array}$ & Neurotoxicity & Comments & Refs \\
\hline Bleomycin & -2.57 & & 1416 & $\begin{array}{l}\text { Intracerebral } \\
\text { administration in } \\
\text { rat } 9 \text { L gliosarcoma. } \\
\text { Administered safely } \\
\text { in liposomes in } \\
\text { human cerebral } \\
\text { glioma. } \\
\text { Given IC in GBM - } \\
\text { safe but efficacy } \\
\text { doubtful. } \\
<25 \% \text { increase in } \\
\text { survival in LMC rat } \\
\text { model }\end{array}$ & $\begin{array}{l}\text { phase } 1 \text { study } \\
\text { IC - no toxicity. } \\
\text { Rat, beagle, } \\
\text { human (phase } 1 \\
\text { IV), depot } \\
\text { preparation }\end{array}$ & $\begin{array}{l}\text { Cycling \& } \\
\text { non- } \\
\text { cycling } \\
\text { cells } \\
\text { M \& G2 } \\
\text { phases } \\
\text { most } \\
\text { sensitive }\end{array}$ & $\begin{array}{l}\text { Vascular necrosis } \\
\text { after IT (beagle), } \\
\text { death after IC } \\
\text { administration in } \\
\text { craniopharyngioma } \\
\text { patient }\end{array}$ & $\begin{array}{l}\text { Antibiotic - binds to } \\
\text { DNA - strand scission }\end{array}$ & $\begin{array}{l}{[25,42,78,} \\
82,88,90, \\
95,96,113]\end{array}$ \\
\hline Busulphan & -0.52 & & 246 & $\begin{array}{l}\text { MB/Glioma/ependy } \\
\text { moma - mice. } \\
\text { Glioblastoma - rat. } \\
\text { MB-mice }\end{array}$ & Rat & Non & $\begin{array}{l}\text { Confusion + } \\
\text { seizures - high } \\
\text { dose. }\end{array}$ & $\begin{array}{l}\text { Irritant. Bifunctional } \\
\text { alkylating agent. Poorly } \\
\text { water soluble however } \\
\text { water-soluble } \\
\text { microcrystalline } \\
\text { formulation } \\
\text { (Spartaject) been } \\
\text { developed. Given IT in } \\
\text { rats, non-human } \\
\text { primates, adults with } \\
\text { LM disease + phase } 1 \\
\text { trial in children with } \\
\text { LMD from brain } \\
\text { tumours }\end{array}$ & $\begin{array}{l}{[3,5,26,} \\
42,51,56, \\
87,95,96, \\
122,130]\end{array}$ \\
\hline
\end{tabular}




\begin{tabular}{|c|c|c|c|c|c|c|c|c|c|}
\hline Carmustine (BCNU) & 1.53 & & 214 & $\begin{array}{l}\text { Intravenous } \\
\text { preparation } \\
\text { licensed in } \\
\text { brainstem glioma, } \\
\text { MB, astrocytoma, } \\
\text { ependyoma, and } \\
\text { metastatic brain } \\
\text { tumours. } \\
\text { GLIADEL Implant } \\
\text { licensed in high- } \\
\text { grade malignant } \\
\text { glioma and GBM. }\end{array}$ & $\begin{array}{l}\text { IT - in hybrid } \\
\text { liposomes - rat } \\
+ \text { dog }\end{array}$ & Non & $\begin{array}{l}\text { Convulsions, } \\
\text { cerebral oedema in } \\
\text { patients with } \\
\text { implants. No } \\
\text { Adverse Drug } \\
\text { Reactions, non- } \\
\text { toxic in rat/dog in } \\
\text { liposomes. Acute } \\
\text { encephalopathy } \\
\text { after intracarotid } \\
\text { administration, } \\
\text { encephalomyelopat } \\
\text { hy - coma + death } \\
\text { with high dose, } \\
\text { neuroretinitis }\end{array}$ & $\begin{array}{l}\text { Alkylating and } \\
\text { carbamoylating agent. } \\
\text { DNA alkylation followed } \\
\text { by protein } \\
\text { carbomoylation. } \\
\text { Causes local venous } \\
\text { irritation }\end{array}$ & $\begin{array}{l}{[2,9,29,} \\
42,46,48, \\
64,71,72, \\
85,87,95, \\
96,128, \\
130,136, \\
143]\end{array}$ \\
\hline Dacarbazine & -0.24 & 4.42 & 182 & $\begin{array}{l}\text { Melanoma - } \\
\text { including primary } \\
\text { CNS }\end{array}$ & $\begin{array}{l}\text { Rat. } \\
3 \text { case reports } \\
\text { human patients }\end{array}$ & Non & $\begin{array}{l}\text { Very toxic in rat. } \\
\text { CNS reaction in one } \\
\text { patient case report }\end{array}$ & $\begin{array}{l}\text { Requires demethylation } \\
\text { for activation, though } \\
\text { dacarbazine itself } \\
\text { shows cytotoxic } \\
\text { activity. } \\
\text { Irritant-extravasation } \\
\text { causes tissue damage } \\
+ \text { severe pain }\end{array}$ & $\begin{array}{l}{[9,12,34,} \\
42,78,85, \\
87,95-97, \\
145]\end{array}$ \\
\hline Fazarabine & & & 496 & $\begin{array}{l}\text { Lack of activity in } \\
\text { phase } 2 \text { trial high } \\
\text { grade glioma. Solid } \\
\text { tumour activity + } \\
\text { leukaemia } \\
\text { xenografts. } \\
\text { Potentially useful } \\
\text { for NM from a } \\
\text { variety of tumours }\end{array}$ & $\begin{array}{l}\text { IT + IV } \\
\text { (Ommaya } \\
\text { reservoir) in } \\
\text { Rhesus } \\
\text { monkeys }\end{array}$ & $\begin{array}{l}\text { Probably } \\
\text { s-phase }\end{array}$ & $\begin{array}{l}\text { Transient changes } \\
\text { in CSF profiles but } \\
\text { no evidence of } \\
\text { neurotoxicity after } \\
\text { IV in monkey }\end{array}$ & $\begin{array}{l}\text { Cytarabine analogue. } \\
\text { Inhibits DNA synthesis } \\
+ \text { methylation. } \\
\text { Nucleoside metabolite, } \\
\text { intracellular activation } \\
\text { needed by } \\
\text { deoxycitidine kinase. } \\
\text { Clearance from CSF } \\
\text { five times higher than } \\
\text { CSF bulk flow rate in } \\
\text { monkey }\end{array}$ & $\begin{array}{l}{[60,95,96,} \\
119]\end{array}$ \\
\hline $\begin{array}{l}\text { Ranimustine } \\
\text { (MCNU) }\end{array}$ & -1.29 & & 328 & $\begin{array}{l}\text { pilocytic } \\
\text { astrocytoma }\end{array}$ & $\begin{array}{l}\text { Longer half life } \\
\text { than ACNU in } \\
\text { dogs. } \\
\text { IT admin in } 21 \\
\text { patients } \\
\text { (including } \\
\text { children) with } \\
\text { refractory } \\
\text { disseminated } \\
\text { MB showed } \\
\text { efficacy in }\end{array}$ & Non & $\begin{array}{l}\text { Mild histological } \\
\text { changes in dog } \\
\text { brain after IV } \\
\text { admin. IC admin } \\
\text { caused marked } \\
\text { brain oedema + } \\
\text { focal necrosis. } \\
\text { Paraplegia + double } \\
\text { incontinence in } \\
\text { some patients } \\
\text { receiving multiple }\end{array}$ & Nitrosourea & $\begin{array}{l}{[42,74,87,} \\
95,96,98, \\
146,149]\end{array}$ \\
\hline
\end{tabular}




\begin{tabular}{|c|c|c|c|c|c|}
\hline & & some. & IL bolus injections & & \\
\hline Zinostatin & $\begin{array}{l}\text { Glioblastoma, } \\
\text { astrocytoma }\end{array}$ & $\begin{array}{l}\text { single case } \\
\text { report }\end{array}$ & $\begin{array}{l}\text { No CNS toxicity } \\
\text { when given via } \\
\text { carotid artery }\end{array}$ & $\begin{array}{l}\text { Antineoplastic } \\
\text { antibiotic. } \\
\text { Does not permeate } \\
\text { BBB in normal brain. } \\
\text { Half life CSF }=50 \mathrm{sec}\end{array}$ & $\begin{array}{l}{[74,87,95,} \\
96,98,146]\end{array}$ \\
\hline
\end{tabular}


Table 6: Comparison of candidate intrathecal agents by previous published reviews

\begin{tabular}{|c|c|c|c|}
\hline Fleischack [49]. & Ruggiero [108]. & Blaney [17] & Conroy \\
\hline \multicolumn{4}{|l|}{$\begin{array}{l}\text { Intracavitary } \\
\text { bleomycin }\end{array}$} \\
\hline & & & Carboplatin \\
\hline Cytarabine & Cytarabine & & \\
\hline $\begin{array}{l}\text { Liposomal cytarabine } \\
\left(\text { DepoCyte }^{T M}\right)\end{array}$ & $\begin{array}{l}\text { Liposomal cytarabine } \\
\left(\text { DepoCyte }{ }^{T M}\right)\end{array}$ & $\begin{array}{l}\text { Liposomal cytarabine } \\
\text { (DepoCyte }^{\mathrm{TM}} \text { ) }\end{array}$ & $\begin{array}{l}\text { Liposomal cytarabine } \\
\text { (DepoCyte }^{\mathrm{TM}} \text { ) }\end{array}$ \\
\hline Diaziquone & & & Diaziquone \\
\hline \multirow[t]{3}{*}{ Etoposide } & & & Etoposide \\
\hline & & & Floxuridine (FdUrd) \\
\hline & & & $\begin{array}{l}\text { 4-Hydroxyperoxy- } \\
\text { cyclophosphamide }\end{array}$ \\
\hline Mafosfamide & Mafosfamide & Mafosfamide & Mafosfamide \\
\hline Mercaptopurine & Mercaptopurine & & Mercaptopurine \\
\hline \multirow[t]{2}{*}{ Methotrexate } & Methotrexate & & \\
\hline & $\begin{array}{l}\text { Monoclonal } \\
\text { antibodies }\end{array}$ & & \\
\hline \multirow[t]{4}{*}{ Nimustine (ACNU) } & & & Nimustine (ACNU) \\
\hline & & & Rubitecan \\
\hline & Temozolomide & & Temozolomide \\
\hline & Thiotepa & & \\
\hline Topotecan & & Topotecan & Topotecan \\
\hline
\end{tabular}


